\title{
Kauzalita činitele ve světle kompatibilistické kritiky
}

\author{
Petr Dvořák \\ Filosofický ústav \\ Akademie věd České republiky \\ Jilská 1, 11000 Praha \\ petr.dvorak@flu.cas.cz
}

Článek souhrnně odpovídá na vybrané podněty a námitky čtyř textů, jež polemizují s některými aspekty Dvořákovy knihy Kauzalita činitele (Togga 2020). Ve vztahu k článku J. Peregrina vysvětluje, proč nelze přijmout jeho řešení antinomie mezi svobodným rozhodováním a determinismem oddělením dvou druhů jazyků či výkladových rámců. Kritiku S. Sousedíka Dvořák považuje za založenou na př́liš úzkém pojetí schopnosti. Odmítá to, že by z pojmu schopnosti plynulo, že ta může být determinována pouze něčím jiným, než je její nositel. Podstatnou část námitky D. Peroutky Dvořák přijímá a upřesňuje, nakolik je existence alternativních možností nutnou podmínkou svobodného charakteru rozhodování. Konečně, v polemice s V. Punčochářem se Dvořák snaží vyložit, ve kterém smyslu náhoda ruší svobodu a ve kterém nikoliv. Dále, autor nepovažuje epistemické alternativy za dostatečné pro skutečnou svobodu rozhodování.

Klíčová slova: svoboda vůle, kauzalita činitele, inkompatibilismus, kompatibilismus

Následující pojednání si klade za cíl stručně odpovědět na kritické články kolegů, které se věnovaly některým aspektům mé knihy Kauzalita činitele ${ }^{1}$. Kritiky spojuje náklonnost ke kompatibilismu, byt u každého trochu jiná. Např́íklad pan profesor Stanislav Sousedík je zastáncem teologického kompatibilismu, David Peroutka pak racionálního kompatibilismu v oboru finální kauzality. Zároveň však mezi námi panuje

1 Dvořák (2020). 
shoda ohledně platnosti koncepce kauzality činitele. Toto pojetí lze totiž zastávat nezávisle na tom, na jakou stranu se přikloníme ve sporu mezi kompatibilismem a inkompatibilismem. Pan profesor Jaroslav Peregrin a Vít Punčochář představují zásadnější kritický hlas. Lze je také řadit mezi kompatibilisty, ale navíc odmítají i teorii kauzality činitele. Oběma je společná sympatická snaha určité inkompatibilistické intuice uchovat rozlišením perspektiv či jazyků.

Všem čtyřem kolegům jsem vděčný za kritickou pozornost, kterou mé knize věnovali, a redakci časopisu za tuto diskusní př́ležitost. Předem se omlouvám, že není možné reagovat na všechny vznesené podněty. Odpověd’ je tedy někdy možná až př́liš stručná. Snažil jsem se vždy vystihnout jádro sporu. Někdy by obhajoba vyžadovala rozsáhlejší pojednání, které by vybočilo z rámce problematiky svobody rozhodování, takže jsem se tímto směrem ani nepokoušel vydat.

Knihu jsem věnoval panu profesoru Peregrinovi, proto hodlám nejprve reagovat na jeho článek. Pan profesor ve svém obecněji pojatém př́spěvku „Jak filosofovat o lidské mysli? “2 upozorňuje (mj. v duchu Davidsonova anomálního monismu) ${ }^{3}$ na skutečnost, že existují dva nesouměřitelné přístupy a jazyky ve vztahu k vysvětlování mentální kauzality a fenoménu rozhodování a jednání: vědecký deterministický kauzální model a mentalistický jazyk běžného vysvětlování lidského jednání. Ústřední námitka pana profesora vưči mé argumentaci, resp. jejím závěrům, spočívá v tom, že oba jazyky nelze integrovat do jednoho pojmového výkladového modelu, jak to činí př́istup, který ve své práci volím já. Námitce rozumím, jedná se o vnější typ námitky v tom smyslu, že vychází z odlišného obecnějšího pojetí filozofie. Obecnějším pojetím filozofie míním určitý epistemologický a určitý metafyzický rámec, jež charakterizují odpovědi na otázky, co vše lze poznat, a v návaznosti na to, co existuje, jak věci jsou. Metafyzické realistické stanovisko, v jehož rámci se moje argumentace pohybuje, předpokládá, že existuje na poznání nezávislý strukturovaný svět, který našimi pojmovými systémy lépe či hưře

2 Peregrin (2021).

3 Původní formulace Davidsonova anomálního monismu se nachází v článku „Mental Events“ z r. 1970, Davidson (2001). 
zachycujeme a vykládáme. Nesouměřitelnost je vždy známkou toho, že jeden výklad je horší než jiný ve vztahu k téže vysvětlovací funkci, kterou představuje pravdivý popis ve smyslu adekvační teorie pravdy (výrok je pravdivý právě tehdy, když skrze něj náš rozum zpřítomňuje aktuální stav světa). ${ }^{4}$ Fakt, že jsou dva výklady skutečnosti nesouměřitelné, znamená následující: jedno vysvětlení sestává z určité kategorizace skutečnosti a z určitých tezí, které alespoň prima facie odporují tezím jiného vysvětlení s jinou kategorizací, přičemž ony klíčové kategorie (a teze o nich) se mají týkat stejných jevů. Například skutečnost, že mě bolest zubu vede $\mathrm{k}$ rozhodnutí objednat se $\mathrm{k}$ lékaři, lze vysvětlit fyzikalisticky jako kauzální vztah mezi komplexními fyzickými stavy v mém mozku, mezi stavem, který nazýváme bolestí, a stavem, který označujeme jako rozhodnutí k nějaké činnosti. První stav je postačující příčinou druhého. Ve výkladu, který používá mentalistické kategorie bolesti a rozhodnutí, jde rovněž o svého druhu kauzální vztah, ale první (bolest) není postačující př́ičinou druhého (rozhodnutí), protože rozhodnutí považujeme za svobodné v duchu inkompatibilistické svobody. První jazyk implikuje, že do kauzálního vztahu vstupují fyzické objekty (objekty jiného typu nepotřebujeme), druhý jazyk, že existují také mentální objekty, a že ty jsou členy kauzálního vztahu. Tentýž jev je zároveň modelován jako fyzický i mentální. Tedy prima facie je zde rozpor: $Z$ realistické pozice plyne, že nakolik je objekt kauzálně aktivní, je bud' fyzický, nebo mentální. Nemůže být zároveň fyzický a působit deterministicky a mentální a působit indeterministicky, protože i účinek by byl fyzický i mentální zároveň a jeho existence by byla vzhledem k výskytu příčiny nutná a nahodilá zároveň, což je spor (J. Peregrin v této souvislosti trefně zmiňuje Kantovu třetí antinomii, která přesně tento spor zachycuje) ${ }^{5}$. Realistické stanovisko tedy implikuje, že jen jeden z výkladů může být správný. Naproti tomu antirealistické stanovisko (v širším smyslu), které v určité podobě zastává prof. Peregrin, hovoří o dvou ontologických modelech, mezi nimiž není možno ani nutno rozhodnout a které mohou existovat zároveň, plní-li své funkce, které se patrně neomezují jen na vysvětlení a predikci

4 Hovořím raději o adekvační než korespondenční teorii, protože druhá může implikovat reprezentacionalismus, kterému se usiluji vyhnout. K tomuto rozdílu a k adekvační teorii srov. Novák \& Vohánka (2015, kap. 4).

5 Peregrin (2021, s. 37). 
budoucích jevů. Pokud tvrzení neposuzujeme podle adekvátnosti, s níž vyjadřuje skutečnost, ale nakolik jsme oprávněni jej tvrdit (vzhledem k jiným tvrzením, která zastáváme), tedy v duchu koherence určitého obrazu světa, pak lze přijmout nesouměřitelné popisy bez nutnosti hledat prostor pro indeterminismus $\mathrm{v}$ analýze fyzických procesů $\mathrm{v}$ mozku, skrze něž či s jejichž pomocí se uskutečňuje to, co mnozí chápou jako mentální kauzalitu.

Neshoda se tedy netýká jen dílčích argumentů a jejich konkluzí, ale epistemologicko-metafyzických rozvrhů (realismus vs. antirealismus či konstruktivismus), z nichž vyplývají i určité metodologické závazky či nároky na řešení dané problematiky. Obhajoba metafyzického realismu přesahuje možnosti této stručné odpovědi. Čtenáře případně odkazuji na zdařilou knihu L. Nováka a V. Vohánky ${ }^{6}$. Domnívám se, že př́ispěvek profesora Peregrina dobře poukazuje na hlubší předpoklady či základy, na nichž diskuse o svobodě vůle $\mathrm{v}$ analytické tradici staví. Peregrinovo řešení v duchu Davidsonova anomálního monismu či Kantovy třetí antinomie nemohu přijmout, protože moje přesvědčení o povaze skutečnosti a jejím poznání mě zavazují hledat řešení, která nesouměřitelnost považují za v principu dočasný epistemický deficit odstranitelný dalším empirickým bádáním a filozofickou analýzou.

V polemickém příspěvku „Kauzalita a kontingentní sebedeterminace?" ${ }^{\text {7 }}$ považuje pan profesor Stanislav Sousedík za sporné, aby se schopnost (a vůle je takovou schopností chtít) sama sebe determinovala. Svou determinaci musí přijímat od vnější příčiny. Domnívám se, že vymezení schopnosti takové, které nabízí pan profesor Sousedík, je př́liš úzké. Je také třeba rozlišit vymezení $\mathrm{v}$ řádu finální kauzality a v řádu účinné kauzality. Vůle se vymezuje sama v řádu účinné kauzality tak, že se přiklání $\mathrm{k}$ některému $\mathrm{z}$ vymezení $\mathrm{v}$ oboru finální kauzality, tj. $\mathrm{k}$ některému $\mathrm{z}$ intelektem nahlédnutých motivů (tyto pochopitelně pocházejí z intelektu, ne z vůle, takže motivy, tj. možná zaměření, možná vymezení vůle, jsou vůli vnějšši). Tudíž při vymezení vůle je zde aspekt účinný a finální. První činí vůle zcela sama, ke druhému využívá to, co jí představuje intelekt.

6 Novák \& Vohánka (2015).

7 Sousedík (2021). 
To je podstatou kontingentní sebedeterminace vůle, která je $\mathrm{v}$ tomto zcela výjimečnou schopností a, jak se coby křestanský teista domnívám, $\mathrm{v}$ tomto je člověk obrazem Božím (jak zmiňuje i podle slov pana profesora Descartes) ${ }^{8}$. V tomto se vůle liší od pasivní schopnosti, jíž je schopnost vosku prijímat tvary, ale i od jiných aktivních schopností, jako je schopnost zrakového vidění či schopnost sluchová. Jen takové pojetí vůle může založit mravní odpovědnost za jednání v plnohodnotném smyslu, protože za to, co uvidím či uslyším, nemohu nést žádnou odpovědnost, to se přihází nutně. Kdyby tedy vůle byla takovou schopností, jak schopnost vymezuje S. Sousedík, nebyla by svobodná.

David Peroutka ve svém příspěvku „Volitelova sebedeterminace v kompatibilistické verzi“9 ${ }^{9}$ právem poukazuje na to, že (libertariánské) inkompatibilistické stanovisko, které hájím, staví na principu alternativních možností (Principle of Alternate Possibilities , PAP). To znamená, že nutnou podmínkou svobody rozhodování a jednání je, že bezprostředně před rozhodnutím existuje reálná možnost daným způsobem nejednat. ${ }^{10}$ V knize podle Peroutky dostatečně nehájím nutnost zmíněného principu (PAP), ani se nevyrovnávám se současnou sofistikovanou kompatibilistickou argumentací. V tom má jistě pravdu. Stál jsem před volbou, co na omezené ploše zmínit a rozpracovat. $\mathrm{S}$ ohledem na cíl, jímž bylo na prvním místě hájit kauzalitu činitele, a až na druhém pak samotný inkompatibilismus, jsem zvolil argumentaci namířenou proti nereduktivnímu fyzikalismu a ve prospěch nějakého druhu dualismu. To jsou nutné předpoklady, na nichž přijatelnost kauzality činitele stojí a s nimiž také zřejmě padá. Šlo mi o rehabilitaci určité filozofické pozice alespoň v tom smyslu, že je filozoficky hodnotné se jí zabývat (proti námitce z mysterianismu a automatickému předpokladu, že se v oblasti filozofie mysli kauzalita týká výlučně událostí. Proto jsem D. Peroutkovi vděčný za to, že $\mathrm{v}$ tomto duchu mou argumentaci doplňuje a poukazuje na místa, kde je zapotřebí mé teze podložit propracovanějšími argumenty či dále analýzu

8 Tamtéž, s. 45 .

9 Peroutka (2021).

10 „Reálnou možností“ se na tomto místě na rozdíl od „logické či metafyzické možnosti“ míní uskutečnitelnost, tj. možnost, kterou může přesně za dané situace aktualizovat některá z existujících prŕčin. $V$ našem případě je touto příčinou pochopitelně činitel sám. 
zjemnit. Peroutka je zastánce kauzality činitele jako já. Ovšem ve vztahu ke sporu kompatibilismu a inkompatibilismu zastává diferencovanější pozici. V tom se podobá Thomasi Pinkovi, z jehož díla jsem hojně čerpal a který v pozdějších pracích zastává vi̊či danému sporu spíše agnostické stanovisko s tím, že se kloní ke kompatibilismu (podle něj není pravda, že každá determinace činitele $\mathrm{k}$ volbě ruší jeho svobodu). ${ }^{11}$ Peroutkovo stanovisko je, dalo by se říci, hybridní: v př́ípadě zlých voleb je inkompatibilistou (musí existovat alternativa k provedené volbě), ovšem v prŕpadě dobrých voleb alternativa existovat nemusí. Rozhodnutí je svobodné i bez ní. Poukazuje na důležitou asymetrii: U špatných voleb je př́padná alternativa ve shodě s tím, co má být, a pokud „měl učinit“ předpokládá „mohl učinit“, pak zde morální odpovědnost vyžaduje existenci reálné alternativy před daným rozhodnutím. U mravně dobrých voleb to tak není, špatné alternativy předem existovat nemusejí.

D. Peroutka vychází z intuic, z mravního vědomí. S jeho obhajobou užití intuic $v$ argumentaci souzním. V zásadě odmítá, že bychom posuzovali dobré rozhodnutí, které činitel v určité situaci musel učinit, tj. neměl alternativu, například díky svému charakterovému založení, za méně záslužné a za nesvobodné. Zde bych ovšem diferencoval. Zdá se mi, že se zásluha umenšuje, pokud je volba výsledkem přirozeně daného osobnostního nastavení a nikoliv charakterového nastavení, které bylo postupně získáno správnými volbami za existence reálných alternativ špatných voleb, alespoň v počáteční fázi budování charakteru (o nichž hovoří Kane, kterého Peroutka zmiňuje). Pokud „nést morální odpovědnost za jednáni“ znamená připsatelnost viny za špatné rozhodnutí (a jednání) a zásluhy za dobré rozhodnutí (a jednání), pak se umenšuje i morální odpovědnost za takové jednání, byt' dobré. Je jistě rozdíl mezi situací, kdy člověk popsaným způsobem (v Kaneově duchu sebe-budujících voleb) ${ }^{12}$ vytvoří v čase dobrý charakter do té míry, že ten odstraňuje reálnou alternativu mravně špatných voleb, a situací, kdy mu je tento charakter dán bez jeho přičinění. Řekněme, že by bylo v technických možnostech neurověd změnit nějakým neinvazivním zásahem rozhodování člověka tak, že by pro něj mravně špatné volby přestaly být reálnou alternativou

11 Pink (2016, např. s. 3).

12 Např. Kane (2005, s. 129-131). 
a musel v každé situaci volit dobro (či by alespoň volil dobro s vysokou mírou pravděpodobnosti). Fakt, že tuto úpravu, i když by byla zdravotně zcela bez rizik, automaticky nespatřujeme jako žádoucí pro každého, kdo dobrý charakter dosud nemá (at’ už tím, že jej nevybudoval, nebo tím, že mu nebyl dán přirozeně), znamená, že v morální oblasti spatřujeme rozdíl mezi jednáním, které vychází z charakteru budovaného vlastní pílí ze situace, kdy jsou zlé volby reálné, a jednáním, které vychází z charakteru, který tuto „plnohodnotnou“ či „mravně nebezpečnou“ volbu nikdy neumožnil. Nevím jak David Peroutka, ale já mám tuto intuici silnou.

Zdá se, že zásluha je tím větší, čím reálnější (pravděpodobnější) je možnost selhat. Dá se však říci, že pokud by zde reálná možnost selhat vůbec nebyla, jednání by nebylo svobodné? Zde dávám Davidovi Peroutkovi za pravdu, že nejspíše ne. Pro křest’anského teistu je tato odpověd' navíc důležitá také proto, že křest’anský Bůh nemá reálnou alternativu volit zlo díky své přirozenosti (je maximálně dobrý), a přesto je považován za maximálně svobodného. Existence reálné možnosti zlé volby tedy nemůže být nutnou podmínkou svobody v tom smyslu, v němž má svobodu Bůh (existuje-li). Tato problematika již přesahuje čistě filozofický zájem většiny čtenářoo. Stojí však za zmínku, že se zde setkávají dvě v určitých rysech protichůdná pojetí svobody rozhodování - obě s antickými kořeny -, která se např. jednotliví scholastičtí filozofové snažili sladit a vyvážit: svoboda daná alternativními možnostmi a svoboda jako absence překážek aktualizace možnosti správné volby. Napětí mezi nimi spočívá v tom, že se zdá, že svoboda ve druhém smyslu narůstá, když se umenšuje první (s ohledem na zlé alternativy). Totální absence zlých alternativ neruší svobodu ve druhém smyslu, naopak ta je největší (to je zmíněný případ Boha). Důvod, proč se na rozdíl od správné volby vyžaduje existence alternativy při zlé volbě, je nasnadě: je-li primárním významem „svobody“ absence překážek aktualizace možnosti jednat správně, pak se zde reálná možnost jednat správně předpokládá.

Přesto na základě toho, co bylo řečeno, se zdá, že míra záslužnosti jednání nekopíruje prostou míru, s níž absentují překážky aktualizace správného jednání, nýbrž že odstranění překážek musí být dílem činitele, jinak je méně záslužné (přirozená danost) či záslužné minimálně (v případě neuro-programování). Se stupňovatelným pojmem zásluhy 
se nutně pojí míra, s níž je zapotřebí překonávat překážky. Podobně jako u sportovních výkonů (např. vylézt na Mount Everest s kyslíkem a bez). Tím se dostáváme k otázce determinace a její slučitelnosti se svobodou rozhodování a jednání. Aby bylo jednání svobodné, nesmí determinace odstraňovat ze hry činitele coby kauzální zdroj či počátek jednání. Jedna věc je pomoc (např. kyslík při výstupu, Boží milost v teologii), která umožňuje jednání činiteli uskutečnit, druhá pak determinace činitele k tomuto jednání, příčinný vliv, aby jednal určitým způsobem. Zde jsme ovšem patrně s D. Peroutkou ve shodě. Nepřímá determinace motivů (ve smyslu finální kauzality) není se svobodným charakterem rozhodnutí a z něho plynoucím jednáním v rozporu. Přímá determinace vnějších příčin (ve smyslu eficientní kauzality) svobodu odstraňuje.

Jistě existuje vícero vymezení pojmu morální odpovědnosti. Pokud morální odpovědnost vymezíme úzce jako připsatelnost zásluhy v základním smyslu (basic desert sense), tj. možnost jednání hodnotit jako chvályhodné či jako něco, za co je aktér viněn, pak morální odpovědnost vyžaduje, aby jednání bylo svobodné, ale naopak to, zdá se, neplatí. Některá svobodná jednání nejsou takto hodnotitelná.

Je tedy třeba na základě výše uvedených vyjasnění a zpřesnění opustit myšlenku, že svobodné rozhodnutí uskutečňuje výlučně kontingentně se determinující činitel? Přesněji řečeno, že je třeba vypustit výraz „kontingentní“, pokud tím míníme, že musí existovat reálná možnost opaku? Reflektujeme-li faktický stav, realita zlých voleb se zdá existovat téměř vždy pro každého činitele (s výjimkou Boha). Proto in statu viae se zdá být existence alternativních možností nutnou podmínkou svobody rozhodování. Je rovněž principiální nutnou podmínkou za všech okolností? Zde se kloním k D. Peroutkovi, že zřejmě nikoliv. Lze totiž myslet situaci, kdy racionální činitel poznává, že má jedinou správnou volbu, jeho charakter je od přirozenosti takový, že volbu zla reálně neumožňuje, a neučinit rozhodnutí by rovněž bylo zlem. Přitom k volbě není ničím eficientně determinován, je jejím výlučným zdrojem. Jedná přesto svobodně? Domnívám se, že ano. Zatím nespatřuji dostatečný důvod trvat na tom, že musí mít reálnou možnost rozhodnutí neučinit (ve smyslu svobody výkonu) či dokonce mít vždy vícero dobrých alternativ (ve smyslu svobody specifikace). Na druhou stranu s výjimkou Boha zde vždy musí existo- 
vat alternativa ve smyslu metafyzické možnosti učinit opak. Pro každého takového činitele platí, že jeho charakter mohl být jiný. Pokud tedy v jednom možném světě nemá jinou volbu, v jiném to neplatí. V tomto smyslu je zřejmý rozdíl mezi kontingentním činitelem a nutnou příčinou, u níž neexistuje metafyzicky možná alternativa opaku. Hovoříme-li tedy o lidských svobodných rozhodnutích a jednáních, o lidském činiteli, pak je kontingentně se determinující př́činou v metafyzickém smyslu.

Vít Punčochář ve svém jasném a dobře vyargumentovaném textu „Jak je možná svobodná volba v deterministickém světě“"13 zastává velmi silnou tezi, že každé vysvětlení musí být vysvětlení kontrastní (contrastive), přinejmenším v oblasti vysvětlování lidského jednání, má-li člověk být ve svém jednání svobodný: Chceme-li vysvětlit, proč nastal jev $A$, musíme zároveň vysvětlit, proč nenastal jev $B$, který mohl reálně nastat místo $A$ (a každý další takový jev, existuje-li pouhá možnost, že by nastal). Takto silná podmínka kladená na vysvětlení implikuje, že vysvětlení $A$, tj. důvod, proč $A$ nastává, at už kauzální nebo nekauzální, musí vzhledem k nastávání jevu $A$ představovat postačující podmínku. ${ }^{14} \mathrm{~V}$ oblasti kauzálního vysvětlování jednání pomocí motivů pak zmíněná potřeba postačující podmínky znamená platnost kauzálního determinismu.

A proč takto silné pojetí vysvětlení v případě lidského jednání zastávat? Punčochář říká: „[Absentuje-li podobné vysvětlení,] pak to ale vypadá, že výsledek rozhodnutí, k němuž reálně došlo, je určen pouhou náhodou, která je však se svobodou neslučitelná." ${ }^{15}$

Takže V. Punčochář nás staví před dilema „bud’ je moje jednání výsledkem kauzálního determinismu, nebo je náhodné, a tudíž není svobodné“. V dalším pak obhajuje kompatibilitu určitého pojetí svobody s tímto deterministickým vysvětlováním i morální odpovědnosti za jednání.

13 Punčochář (2021).

14 Punčochář píše: „Abychom mohli A považovat za důvod dostatečně vysvětlující B, musí A nějakým zpo̊sobem implikovat $B$, což znamená, že když zafixujeme relevantní okolnosti, a přitom platí $\mathrm{A}, \mathrm{s}$ určitou mírou nutnosti musí platit i $\mathrm{B}$. Důvod samožrejmě nemusí mít vždy podobu příčiny, jako ho nemá například matematické zdůvodnění, ale vždy by měl mít za daných okolností charakter postačující podmínky."Punčochář (2021, s. 76).

15 Tamtéž, s. 74. 
Předně je třeba říci, že se běžně spokojujeme s vysvětleními, která kontrastní nejsou: „Proč jsi šel do kuchyně? Protože jsem měl hlad.“ Fakt, že jsem měl hlad (a měl jsem touhu jíst) a sdílené přesvědčení, že v kuchyni je jídlo, nepředstavují postačující podmínku pro skutečnost, že jsem šel do kuchyně. Mohl jsem svou touhu ignorovat nebo jít jinam. To by bylo zcela slučitelné s daným motivem i přesvědčením. Dokonce nejsou ani podmínkou nutnou. Podobně: Proč jsi koupil auto? Protože chci jezdit do práce. Uvedený důvod nevysvětluje, proč si člověk auto nepůjčil, proč se nedomluvil na spolujízdě atd. Přesto vysvětlení jednání uvedením nekontrastních důvodů dostačuje a konání nepovažujeme za náhodné a nesvobodné. $K$ vysvětlení našeho jednání plně stačí coby důvod určitý přiměřený motiv, ${ }^{16}$ třebaže ten nevysvětluje, proč jsme neučinili množství dalších věcí, které bychom učinit mohli. Motiv nemusí být takový, aby vyloučil všechna ostatní v dané situaci možná jednání. Ve skutečnosti by nám ve většině př́ípadů kontrastní vysvětlení přišla jako nepřiměřená, jako jistý druh kauzální přeurčenosti. Na otázku, proč za námi student přišel, nepotřebujeme, ani nechceme slyšet, proč nedělal vše ostatní, co dělat ve své situaci mohl.

Náhoda, která by rušila svobodu, totiž vyžaduje něco jiného než absenci kontrastního vysvětlení. Je otázka, zda i jednání bez motivu nemůže být svobodné, tj. zda svoboda jednání je vůbec nějak odvislá od existence vysvětlení tohoto jednání. Je zřejmé, proč Punčochář spojuje umenšení svobody s náhodou a tu s absencí vysvětlení. V modelu, který zastává, jednání kauzálně působí motiv spolu s dalšími stavy (přesvědčení), at už ty chápeme jako mentální či v duchu reduktivního fyzikalismu jako fyzické. Chybí-li dostatečná příčina v podobě těchto mentálních (či fyzických) stavů, výsledné jednání má nezapříčiněné aspekty. My tento model z různých důvodů nepřijímáme, např́íklad proto, že pak nepůsobí činitel, ale jeho stavy a činitel není totožný se souhrnem svých (mentálních či fyzických) stavi̊ (tzv. námitka mizejícího činitele). Podle nás rozhodnutí a jednání působí činitel. Všechny aspekty jednání jsou jím zapříčiněny, jednání tedy není ani zčásti bez příčiny. Motiv není primár-

16 „Přiměřený“ ve smyslu specificity vzhledem k specifickému charakteru vysvětlovaného jednání. Příliš obecný motiv nebývá dostatečným vysvětlením. Právem se žádá bližší určení: Detektiv vyšetřující vraždu se ptá podezřelého: „Co jste dělal na tom místě?“ Patrně se nespokojí s odpovědí „Jel jsem kolem“. 
ně vnitřní mentální stav (touha činit $x$ k získání cíle $C$, kterou předchází touha získat cíl $C$ a přesvědčení, že konání $x$ vede k $C$ ), ale objektivní normativní skutečnost, žádoucí objekt nebo nějak potřebná změna: nejprve je zde potřeba jezdit do práce, kterou poznávám rozumem, až následně na základě tohoto poznání vzniká touha cíl uskutečnit. Zatímco tento mentální stav touhy vzniká na základě poznání samovolně, mentální stav rozhodnutí jednat v souladu s motivem působí svobodně činitel sám a kauzálně jej nepůsobí mentální stav touhy po dosažení cíle jako takový. Motiv, v souladu s nímž se činitel rozhoduje a následně jedná, dává jednání jeho charakter, specificitu, vysvětluje, proč činitel koná $x$, ale pokud chybí, zdá se, že např. fyzický akt může být svobodný i bez motivu rozhodnutí jej konat. Primárně se jedná o svobodu rozhodování, vnější jednání nese tento charakter až derivativně.

Rozhodne-li se činitel konat $x$ proto, že má přiměřený motiv $M 1$ ke konání $x$ a tento motiv je zároveň přiměřeným motivem pro konání $y$, pak fakt, že nic nevysvětluje, proč se rozhodl konat $x$ a nikoliv $y$, nijak neubírá jeho svobodu, tj. kontrolu, vládu, nad konáním $x$. Mám-li hlad a vezmu-li si chleba a nikoliv rohlík (a nedokážu vysvětlit, proč jsem se rozhodl spíše pro chleba než pro rohlík), neznamená to, že si neberu chleba svobodně. To také neznamená, že někdy nemáme další motiv, který vysvětluje kontrastně (rohlík je tvrdý, chleba mi více chutná atd.). Pointa je ale v tom, že i když takový důvod neexistuje, jednání je stále svobodné.

Rozhodne-li se činitel konat $x$ proto, že má přiměřený motiv $M 1$ ke konání $x$, ale zároveň má i motiv $M 2$, který by vysvětloval rozhodnutí nekonat $x$, pak fakt, že zde není motiv, proč dal přednost $M 1$ před $M 2$, opět neruší kontrolu nad daným jednáním. Jistá míra spontánnosti (absence kontrastního vysvětlení, nezdůvodněnosti) at’ už na úrovni samotného konání jako v předchozím odstavci či na úrovni motivů, jako je tomu nyní, nezbavuje jednání svobody. Alespoň mně není zřejmé, proč by měla. Rozhodnutí je mým aktem, nic mě coby činitele k němu nedeterminuje ve smyslu postačující podmínky. Náhodnost, která zbavuje kontroly, znamená, že činitel neovlivňuje, zda a kdy dochází k nějakému aktu, nikoliv že není zcela zřejmé, proč k němu dochází. Učiním-li něco spontánně, učinil jsem to svobodně, třebaže chybí dostatečné vysvětlení 
pro př̌islušné rozhodnutí (chtění). Tím spíše je konání svobodné, je-li vysvětlení dostatečné, třebaže ne kontrastní.

Zdá se, že náhodné rozhodnutí zvednout ruku (náhodné v tom smyslu, že chybí vysvětlení, proč jsem se tak rozhodl) lze považovat za svobodné. Prostě se tak činitel rozhodl bez důvodu. U jednání vyjma rozhodnutí je rozlišení náhodného a nenáhodného snazší: náhodné jednání je takové, kterému nepředchází rozhodnutí činitele. Takové jednání nepovažujeme za svobodné. Situace, kdy bez důvodu zvedám ruku (v tom smyslu, že rozhodnutí ji zvednout nemá důvod) se podstatně liší od situace náhodného zvednutí, které bylo způsobeno nějakým fyziologickým procesem bez činitelova přičinění (rozhodnutí). Zde se objevuje náhodnost v jiném smyslu, jak záhy uvidíme. V prvním případě byl činitel aktivní, ve druhém jen pasivním pozorovatelem dění. Ale otázku, zda lze považovat jednání za svobodné bez jakéhokoliv (nejen kontrastního) vysvětlení, zde nemusíme zodpovídat a můžeme ji nechat otevřenou. Existují dobré důvody se domnívat, že každé rozhodnutí a z něho vycházející jednání je zacílené, takže i ono domněle zcela spontánní rozhodnutí a jednání, nakolik je jednáním, má nutně motiv.

Bud' jak bud', klíčové je, že existují dvě pojetí náhody ve vztahu k jednání: Jednání je náhodné v prvním smyslu, nakolik chybí dostatečné vysvětlení, přičemž dostatečným vysvětlením se nemíní postačující kauzální podmínka, nýbrž vysvětlení přiměřeným motivem. U pojmu vysvětlení je nutno rozlišovat. Vysvětlení jednání uvedením důvodů je vysvětlení ve smyslu finální př́ičiny. Dostatečné vysvětlení nemusí být kontrastní a je otázka, zda svobodné jednání vůbec musí mít tento typ vysvětlení. Pokud se míní vysvětlení jednání pomocí účinné př́íčiny, pak svobodné jednání má vždy vysvětlení, tedy příčinu. Pokud má jednání vysvětlení kontrastní a jeho přičina je kauzálně postačující podmínka, pak nejde o svobodné jednání. Tím, že činitel není tímto druhem příčiny, pak musí jít o př́ičinu jinou.

Ve druhém smyslu je jednání náhodné, pokud není působeno činitelem, ale něčím jiným, než je činitel sám (nějakým fyziologickým procesem), nebo není působeno ničím. K tomuto typu náhodnosti se ještě dostaneme. Klíčové tvrzení je nyní toto: první typ náhodnosti neruší svobodu, druhý ano. Punčochářùv smysl náhody coby nemožnosti predikce 
není přímo totožný ani s jedním z právě uvedených smyslo̊. Důvod, proč zřejmě Punčochář považuje nemožnost predikace za náhodu, je ten, že tato nemožnost je dána absencí příčiny. Absentuje-li příčina, pak činitel nepůsobí jednání a Punčochářovo pojetí náhody se redukuje na náš druhý smysl, který skutečně ruší svobodu. Ale nemožnost predikce neimplikuje absenci příčiny, nýbrž jen naopak. Nakolik je $A$ nezapříčiněné (určité jeho aspekty nemají vůbec přícinu), natolik jej nelze predikovat. Ale pozor, naopak to neplatí: nelze-li predikovat výskyt $A$, neznamená to, že $A$ je nezapříčiněné. Kontingentní příčina zapřričiňuje všechny aspekty $A$ (každý aspekt $A$ je ontologicky závislý na této př́ičině), ale její kontingentní charakter znamená, že není kauzální postačující podmínkou. ${ }^{17}$ Někdy je tedy nemožnost predikce důsledkem toho, že působí jiná než deterministická př́ičina, nikoliv toho, že zde není žádná příčina (v případě indeterministické prríčiny by zde nebyla prríčina jen některých aspektů účinku, jiných ano). Možnost predikce tedy není nutnou podmínkou svobodného charakteru jednání. Není ani podmínkou postačující: existují jednání (či spíše lidská chování), která lze dobře predikovat, ale která jsou náhodná v našem druhém smyslu rušícím svobodu (např. doktor informuje pacienta o tom, že lék má vedlejší účinky a zpơsobuje samovolné pohyby údo̊).

Nakolik je tedy jednání náhodné v tom smyslu, že jej činitel nepůsobí, natolik nad ním nemá kontrolu. V tom případě je ve svém působení bud' kauzálně determinován něčím jiným, nebo něco jiného vnější jednání př́mo působí (např. fyziologický proces), nebo jej nepůsobí nic (připust'me jako teoretickou možnost). Tzv. Standardní argument má pravdu v tom, že o svobodu připravuje jednání jak determinismus, tak indeterminismus. Nemá však pravdivou první premisu, pokud se chápe ve smyslu: bud'to platí determinismus, nebo indeterminismus, což považujeme za falešné dilema (existuje třetí možnost, totiž kontingentní determinace):

1. Bud' je determinismus pravdivý, nebo je determinismus nepravdivý (a platí indeterminismus).

2. Jestliže platí determinismus, nemáme svobodu jednání.

3. Jestliže platí indeterminismus, nemáme svobodu jednání.

4. Tedy, nemáme svobodu jednání.

17 Odlišujeme tedy pojem příčiny od kauzálně postačující podmínky. Existují příčiny, které tento charakter nemají. 
Punčochář má tedy pravdu, že chybí-li možnost predikovat z toho důvodu, že je jednání bez příčiny, pak není svobodné v tom smyslu, že nad ním nemá činitel kontrolu. Je tedy s podivem, že nepřipouští i druhou stranu mince, totiž že kontrolu nad jednáním ztrácí činitel i tehdy, když zde jsou postačující předchůdné kauzální faktory daného rozhodnutí, které činitel nepůsobí. Nad tím, co činitel nepůsobí, nemá činitel kontrolu. Jeho kauzální odpovědnost za jednání je nutnou podmínkou toho, aby nad ním měl kontrolu a eo ipso bylo svobodné. S tím kompatibilista souhlasí. Klíčová neshoda tedy není v tom, zda působení činitele představuje nutnou podmínku vlády nad jednáním, nýbrž v tom, co tvoří postačující podmínku (přesněji: jaké další nutné podmínky jsou zapotřebí, aby spolu s působením činitele představovaly $\mathrm{v}$ úhrnu podmínku postačující). Zda ke kontrole stačí, aby činitel jednání jen působil (přeloženo do jazyka kauzality událostí, aby zde byla určitá kauzální dráha mezi událostmi: vnější faktory prostředí - vnitřní faktory jako motiv, přesvědčení, intence - mentální a fyzické stavy spojené s jednáním), nebo zda je zapotřebí více: aby neexistovala žádná vǔči činiteli vnější postačující kauzální podmínka příslušného činitelova rozhodnutí a tím i jednání. Inkompatibilista tvrdí druhé. Vnější postačující podmínka ruší existenci alternativ (jiné rozhodnutí, žádné rozhodnutí), které se zdají být nutnou podmínkou svobodného charakteru lidského rozhodnutí s tím omezením, jak jej v diskusi s Peroutkou připouštíme výše. Pokud činitel během svého života nemůže učinit či podniknout nic, čím by zneplatnil či změnil antecedentní kauzální faktory, z nichž nutně vyplývá každé jedno jeho rozhodnutí během celého života, pak v relevantním smyslu rovněž nemá nad rozhodnutím a z něj plynoucím jednáním kontrolu.

Je zajímavé, že v jistém smyslu nutnost alternativ připouští i Punčochář. Rozlišuje globální smysl, v němž alternativa neexistuje, a lokální smysl. Já bych řekl, že rozlišení se týká fyzické či metafyzické možnosti na jedné straně a epistemické možnosti na straně druhé. Souhlasím, že rozhodnutí ovlivňuje to, jaké přesvědčení mám. Jsem-li tedy v deterministickém univerzu přesvědčen o existenci nějaké možnosti, výsledné rozhodnutí bude jiné, než pokud bych dané přesvědčení neměl. Relevantní změna příčiny má vliv na charakter účinku. Nicméně nesouhlasím, že by tyto alternativy reálně existovaly. Punčochář píše: 
„Avšak ty možnosti, pro které jsem se ve skutečnosti nerozhodl, nelze pokládat za fiktivní jen proto, že nebyly v deterministickém procesu rozhodování vybrány. Sehrály svoji aktivní roli jako relevantní reálné možnosti, mezi kterými subjekt vybíral či mohl vybírat. “18

Je třeba rozlišit dva významy slova „reálná“ ve spojitosti s možností. ${ }^{19}$ Punčochář tím míní, že přesvědčení o dané možnosti hraje kauzální roli, přispívá k tomu, jaký se realizuje účinek. Možnost však není reálná v tom smyslu, že by existovala objektivně, jinak než pouze v mysli subjektu, který se rozhoduje, jako jeho přesvědčení. V tomto smyslu se jedná o fikci. Pokud např. neexistuje Bůh křestanského teismu (což se osobně nedomnívám), pak lze hovořit o fikci. Přesto má přesvědčení o jeho existence nesporný kauzální vliv. Ze své zkušenosti vím, že v některých situacích bych jednal jinak, pokud bych toto přesvědčení nezastával. Ateista by těžko hovořil o tom, že Bůh je reálný, protože přesvědčení o jeho existenci hraje u věřících kauzální roli. Proto užívat označení „reálný“ v souvislosti s epistemickou možností, o níž jsem přesvědčen, že nemá metafyzický reálný korelát (tj. že nejde o možnost ve skutečnosti) mi přijde podobné jako hovořit o volbách v totalitní diktatuře. Nejde o skutečné rozhodování se, o volbu. Jde o automatický (protože kauzálně deterministický) vznik nějakého rozhodnutí (intence) na základě motivů a přesvědčení, jejichž kauzální roli plně nenahlížím a k jejichž kauzálním antecedentům nedohlédnu. Právě díky této omezenosti poznání mohou zmíněné epistemické možnosti existovat a jevit se jako možnosti reálné, třebaže jejich realita je ve skutečnosti fikcí podobnou tomu, jako když v totalitní společnosti dochází ke „svobodné“ volbě politiků. Ideologicky zmanipulovaný volič, který nezná skutečnost, či který si skutečnost nepřipouští, může být přesvědčen, že jeho volba je reálná, že rozhoduje o výsledku, třebaže výsledek „voleb“ je již dávno určen vládnoucí skupinou. Má sice epistemické možnosti volby různých kandidátů, avšak nikoliv možnost reálnou. Pochybuji, že by Punčochář v tomto

18 Punčochář (2021, s. 80).

19 Nyní je náš kontrast „reálná“ a „nereálná neboli fiktivní“ možnost. Výše v souvislosti s článkem D. Peroutky jsme uvažovali o jiném kontrastu, a to „reálná“ vs. „metafyzická“ či „logická“ možnost. „Reálná“ ve spojení s možností zde tedy nyní míníme v jiném smyslu. 
případě hovořil o skutečné volbě. Volba je tak jen zdáním a vůbec k ní nedochází, pokud nepovažujeme za volbu to, že vzniká rozhodnutí, na jehož vzniku se kauzálně podílelo konkrétní přesvědčení o epistemických možnostech. ${ }^{20}$

\section{Literatura}

Davidson, D. (2001): „Mental Events.“ In Essays on Actions and Events, D. Davidson. 2. vyd., Clarendon Press, Oxford, 2001, (článek vyšel poprvé v r. 1970), s. 207-227.

Dvořák, P. (2020): Kauzalita činitele. Úvod do analytické diskuse o svobodě vưle. Togga, Praha.

Kane, R. (2005): A Contemporary Introduction to Free Will. Oxford University Press, New York.

Novák, L. \& Vohánka, V. (2015): Kapitoly z epistemologie a noetiky. Krystal OP, Praha.

Peregrin, J. (2021): „Jak filosofovat o lidské mysli?“ Filosofie dnes 13 (1): 29-39. Dostupné z www.filosofiednes.ff.uhk.cz.

Peroutka, D. (2021): „Volitelova sebedeterminace v kompatibilistické verzi." Filosofie dnes 13 (1): 47-70. Dostupné z www.

filosofiednes.ff.uhk.cz.

Pink, T. (2016): Self-Determination. The Ethics of Action. 1. díl. Oxford University Press, Oxford.

Punčochář, V. (2021): „Jak je možná svobodná volba

v deterministickém světě." Fỉlosofie dnes 13 (1): 71-88. Dostupné z www.filosofiednes.ff.uhk.cz.

Sousedík, S. (2021): „Kauzalita a kontingentní sebedeterminace? Kritická poznámka ke Dvořákově knize Kauzalita činitele." Fỉlosofie dnes

13 (1): 40-46. Dostupné z www.filosofiednes.ff.uhk.cz.

20 Tato analogie s politickými volbami samozřejmě kulhá v tom, že provedená volba kandidáta nemá žádný kauzální vliv (na to, kdo je reálně zvolen) na rozdíl od deterministické volby, kde je rozhodnutí (intence) kauzálně činné. Analogie má být jen v tom, že v obou případech chybí reálná alternativní možnost, tj. možnost na straně reality, nejen možnost poznávaná. V obou př́padech je výsledek poznatelný předem pro toho, kdo má poznání všech antecedentních kauzálních faktorů. 


\section{Abstract}

\section{Agent Causation in the Light of Compatibilist Criticism}

The paper is a summary reply to selected points and objections raised in four texts which argue against some aspects of Dvořák's book Agent Causation (Togga 2020). In relation to the paper by J. Peregrin it explains why it is not possible to accept his solution to the antinomy of free choice and determinism which would be based on the separation of two types of languages or explanatory frameworks. The criticism by S. Sousedík is regarded as based on too narrow a conception of power. The paper rejects that the concept of power implies that only external agents distinct from the bearer of the power could determine its acts. As for the objection raised by D. Peroutka, most of its critical force is accepted by Dvořák who further qualifies to what extent the existence of alternative possibilities is a necessary condition of the free nature of choice. Finally, in the critical discussion with V. Punčochář, Dvořák attempts to explain in what sense chance is contrary to freedom and in what sense it is not. Furthermore, the author does not consider epistemic possibilities to be sufficient for a real freedom of choice.

Key words: freedom of the will, agent causation, incompatibilism, compatibilism

Dvořák, P. (2021): „Kauzalita činitele ve světle kompatibilistické kritiky.“ Filosofie dnes 13 (1): 89-105. Dostupné z www.filosofiednes.ff.uhk.cz. 